\title{
A Sociological Approach to Institutional Communication: The Public Image in Organizational Administration in Education
}

\author{
Sandro Serpa ${ }^{1,2}$ \\ ${ }^{1}$ Department of Educational Sciences (DCE), University of the Azores, Ponta Delgada, Azores, Portugal \\ ${ }^{2}$ Interdisciplinary Centre of Social Sciences-Campus of the University of Azores, CICS.NOVA.UAc, Portugal \\ Correspondence: Sandro Serpa, Department of Educational Sciences (DCE), University of the Azores, Campus \\ de Ponta Delgada, Apartado 1422, PT-9501-801 Ponta Delgada, Azores, Portugal. Tel: 351-29-665-0000. E-mail: \\ sandroserpa@uac.pt
}

Received: June 9, 2015 Accepted: July 13, 2015 Online Published: December 28, 2015

doi:10.5539/ies.v9n1p79 URL: http://dx.doi.org/10.5539/ies.v9n1p79

\begin{abstract}
Acknowledging that the external context visibly affects any organization, this investigation seeks to constitute a specific contribution to the study of the importance of public image in organizational administration. To that end, a collection and documentary analysis of news stories from the newspaper O Fayalense on the Asylum for the Disadvantaged Children of Horta [Asilo de Infância Desvalida da Horta], an institution located on Faial Island, Azores, Portugal, covering the time period of 1858 to 1895 , is performed. In the presentation and discussion of the results, a comparison is made between two periods that involve a single president because they vary in the type of news stories published (at the level of sources and subjects). It is concluded that the news stories published cover three large types of references, which, given the period in question, vary substantially: factual information (on the celebrations occurring in the asylum, communications about donations received and appreciation of benefactors, or institutional information on the elections of the asylum directorate), praise (regarding the asylum's mission, operation, or administration), and censures (including responses to external criticism, criticism of previous managements, and stories regarding the asylum's precarious circumstances). The implication of the study is that the importance of a positive public image, especially a positive image that is supportive of the leadership, should not be overlooked for the organizational administration to have greater chances of success.
\end{abstract}

Keywords: public image, organizational administration, communications strategy, education, Asylum for the Disadvantaged Children of Horta, O Fayalense

\section{Introduction}

\subsection{Organizations and their Surroundings}

An organization is a complex collective unit with a formal and an informal dimension. The actors (individual and collective) in an organization interact with at least a minimum of coordination and reciprocal expectations to fulfill relatively different roles to achieve internal objectives (not necessarily with the same degree of internal sharing) that are generally externally recognized (but that are not necessarily the internal objectives). The organization influences and is influenced by its surroundings and, over time, produces specific characteristics and dynamics; it has either a structural dimension or a procedural dimension. Consequently, Lima (2011a) calls for the analysis of "organizaction (organization + organizational action)" as "organization in action, i.e., the organization as social unit and as social action" (p. 17), in other words, organization as simultaneously structure and action of organizing.

In the operation of any organization, whether in the delimitation of its organizational design or in the activities that occurs within it, the need to establish some type of relationship with the outside to succeed should always be considered (Alvesson, 2013; Crozier \& Friedberg, 1992; Friedberg, 1993; Hofstede, 2003; Lima, 2011b; Schein, 2010). These types of relationships include, for example, institutional relations with the legal body that regulates the organization's activity, competition with other organizations, and the search for legitimacy of the actions taken by the organization, including how the organization is viewed in the environment where it operates based on its social recognition. 
Even in more extreme situations, as in the case of total institutions, the fulfillment of this need is observed (Goffman, 2007; Serpa, 2015a). Goffman (2007) defines total institutions as "a social hybrid, part residential community, part formal organization" (p. 22). Each of these institutions is defined as being "a residential and work location where a large number of individuals in a similar situation, separated from society at large for a considerable period, lead a closed and formally managed life" (p. 11). Examples include mental hospitals, prisons, convents, concentration camps, and boarding schools.

Based on Goffman's (2007) analysis, it can be concluded that "the institution is not a fully isolated world" (Goffman, 2007, p. 92) because some type of relationship between the organization and the outside always exists (Serpa, 2015a).

It follows that the relationship with the outside is always a profoundly important aspect of organizational administration. This is also true in the present, according to Hilman and Siam (2014), who argue that "today, organizations work in a dynamic and complex environment that is continually changing" (p. 142).

The need for an organization's managers to "create a presentable image" (Perrenoud, 1994, p. 137) is therefore understood. Consider the following:

Even the least challenged leaders of an organization are not, of course, entirely free. Periodically, they are subject to the approval of shareholders, co-operators, and association members. They are equally controlled by the State-especially the administrative, judicial, and fiscal apparatus-and by other organizations, especially those that control access to financial resources, knowledge, and technology, to markets or to users, to different varieties of reputation and of legitimacy. The organizing powers are subject to the control of the media and of public opinion. Finally, they cannot be disconnected from the support and the adherence of part of their team and personnel. (Perrenoud, 1994, pp. 144-145) [emphasis ours]

In organizations that are highly dependent on the outside world in particular, their external image, as one of the elements of the relationship with the outside, can foster a specific strategy on the part of the directorate because "little attention is extended to the link between communication and strategy" (Hilman \& Siam, 2014, p. 143).

\subsection{The Importance of External Image for Asylums for Needy Children and Youths}

The treatment of children and youth in a collective boarding school implemented in asylums occurs in organizations in which individuals live together in a common residence where they sleep, play, and work in the same location that is responsible for the individuals' needs (Goffman, 2007; Serpa, 2015a).

One of these organizations, which are studied here, is the Asylum for the Disadvantaged Children of Horta [Asilo de Infância Desvalida da Horta-AIDH]. Founded in the city of Horta, Faial Island, Azores, Portugal, in 1858, its mission is to provide care for unprotected female children and youth in a boarding-school regime (Fernandes, 2004; Lemos, 1958; Lobão, 1998).

In the period studied here (1858-1895), the number of AIDH residents went from a minimum of six residents in 1858 to a maximum of 25 in 1895 (Lemos, 1958), with some considerable fluctuations.

The relationships of the AIDH with the outside were very important for the procurement of private funding (the primary source of the asylum's funding) and had a strong religious influence (because of the significant Catholic presence in the Christian charity). The asylum's administration also found itself somewhat dependent on the guidelines of the local government authorities (Serpa, 2015b, 2015c).

The urgency of this investigation, which seeks to understand the importance of the AIDH's public image in its organizational administration, is therefore understood. This investigation complements other studies we have performed on the Asylum's relationship with the outside, which were centered on either the need to ensure legitimacy at the time of its founding (Serpa, 2015b) or the role of celebrations and language in the image of the Asylum itself (Serpa, 2013).

\section{Methodology}

\subsection{Objectives of the Investigation}

This investigation was conducted to meet the following research objective: how important is the AIDH's public image in its organizational administration? This objective was subdivided into two objectives: the first is more descriptive in nature, related to understanding the public image, and the second is more interpretive in nature, seeking, whenever possible, to analytically relate the importance of this public image in the Asylum's operation. 


\subsection{Information Collection and Analysis Procedures}

To achieve the proposed objective, a qualitative analysis of new stories published in the newspaper that seems to us most representative of the period covered by this study (from 1858, the date of the asylum's founding, to 1895, the date of the final publication of this weekly newspaper) was performed. The selection of this time frame was intentional; it was based on the ease of access to these documents and the possibility of understanding the importance of the Asylum's public image in the same newspaper during a time period of nearly 25 years.

To that end, first, we performed a documentary analysis, which involved selecting, collecting, and filling a reading grid of the collected news stories and opinion pieces. The following elements were extracted from these documents: reference, type of topic, source(s) of information, and stance with respect to the Asylum (praising, neutral, critical). An inductive analysis followed.

For the documentary analysis, news stories found in the newspaper's archive at the National Library of Portugal were selected, collected, and prepared for analysis (Bardin, 1995). Of the documentation containing explicit reference to the AIDH, consulted according to the dates available for continued direct consultation, the local newspaper $O$ Fayalense (published weekly from $12 / 05 / 1858$ to $07 / 15 / 1895$, the date of its final issue) was selected. This consultation was bounded by two time periods: between 5 December and 15 January, inclusive (covering both the anniversary of the establishment of the Asylum as a special moment when the organization celebrates itself in an Asylum Anniversary Party, which occurs on the Feast of the Holy Innocents in the Catholic Church, and Christmas, which could be a special moment in the AIDH-local community relationship) and between 15 April and 15 July, inclusive (covering the Feast of Saint Anthony). A total of 134 news stories from 131 issues of the newspaper $O$ Fayalense were collected.

An inductive analysis was performed (Bardin, 1995). The selected documents were analyzed, the information contained in them was categorized, and the references in the new stories were grouped into the following topics:

- Type of news stories: factual, from either a source other than the president/directorate of the Asylum (about the Feast of the Holy Innocents, about the Feast of Saint Anthony, or focusing on other ceremonies; about the admission of residents; communications about donations and/or references to benefactors or focusing on the staff) or from the president/directorate of the Asylum (communications about donations and/or references to benefactors, the Feast of the Holy Innocents, the Feast of Saint Anthony, or communications regarding elections);

- Praise for the Asylum from a source other than the Asylum itself: focusing on general praise or praise for the Asylum's mission, its president and/or directorate, or its order and cleanliness;

- Criticism: from either a source other than the Asylum (focusing on criticism of a previous Asylum administration) or from the president/directorate of the Asylum (centered on criticizing the external critics of the Asylum).

This categorization, which was always receptive to emerging clues, resulted in the following set of analytical dimensions: the sharing of institutional information, the need to attract benefactors, times of celebration, the public image of the Asylum, and lastly, the relationship between the Asylum and the newspaper $O$ Fayalense.

\section{Results}

\subsection{Quantitative Comparison of News Stories}

The number of news stories varied annually to a maximum of seven in 1866, 1870,1873, 1874, and 1881 .

For the quantitative analysis of the news stories collected, the stories were divided into three columns, each considering a particular time period (Table 1). 
Table 1. Quantitative comparison of the references found in the collected news stories

\begin{tabular}{|c|c|c|c|c|}
\hline & & \multicolumn{3}{|c|}{ Time interval } \\
\hline & & $\begin{array}{c}1^{\text {st }} \text { Period } \\
(1858-1879)\end{array}$ & $\begin{array}{c}2^{\text {nd }} \text { Period } \\
(1880-1882)\end{array}$ & $\begin{array}{c}3^{\text {rd }} \text { Period } \\
(1883-1895)\end{array}$ \\
\hline \multicolumn{2}{|l|}{ Duration } & 21 years & 2 years & 12 years \\
\hline \multicolumn{2}{|l|}{$\begin{array}{l}\text { News stories } \\
\text { collected }\end{array}$} & 89 & 3 & 42 \\
\hline \multirow{5}{*}{$\begin{array}{l}\text { Factual references } \\
\text { - source: asylum } \\
\text { management }\end{array}$} & & 56 & 1 & 12 \\
\hline & Donations/benefactors & 17 & & 10 \\
\hline & Saint Anthony & 14 & 1 & 1 \\
\hline & Holy Innocents & 13 & & 1 \\
\hline & Elections & 12 & & \\
\hline \multicolumn{5}{|l|}{ - from other sources } \\
\hline & Saint Anthony & 19 & & 11 \\
\hline & Holy Innocents & 17 & 1 & \\
\hline & Donations/benefactors & 9 & & 10 \\
\hline & Other ceremonies & 1 & & 2 \\
\hline & Admission of residents & 1 & & \\
\hline & Staff & 1 & & \\
\hline \multirow{6}{*}{$\begin{array}{l}\text { Asylum praise } \\
\text { - from other sources }\end{array}$} & & 5 & 1 & 16 \\
\hline & General/Mission & & & \\
\hline & Cleanliness and order & 4 & & 3 \\
\hline & Praise of the & & & \\
\hline & management & & 1 & 6 \\
\hline & & 1 & & 7 \\
\hline \multicolumn{2}{|l|}{ Asylum Criticism } & 1 & 0 & 2 \\
\hline $\begin{array}{l}\text { - from asylum } \\
\text { management }\end{array}$ & $\begin{array}{l}\text { Response to outside } \\
\text { critics }\end{array}$ & 1 & & \\
\hline - from other sources & $\begin{array}{l}\text { Criticism of previous } \\
\text { management } \\
\text { precarious circumstances }\end{array}$ & & & 2 \\
\hline
\end{tabular}

1

Note. Some news stories contained several different references that are simultaneously factual and/or praising and/or critical.

For the second time period, which only covers two years (from 1880 to 1882), it was only possible to collect three news stories (one factual reference from a source other than the Asylum about the Feast of the Holy Innocents; a reference from the management of the Asylum about the Feast of Saint Anthony; and a praising reference to the existence of order and cleanliness in the Asylum). Because this small number of references does not allow the extraction of basic conclusions, we will focus on the first and third time periods.

There were similarities and substantial differences between the first and third periods. The similarities that stood out were found in the type of factual news stories from a source other than the president/directorate of the Asylum, the most common being references to the Feast of Saint Anthony and the Feast of the Holy Innocents and references to donations and benefactors. There were also similarities in the factual references from the source Asylum president/directorate in which the communication of donations and/or references to benefactors 
was the most common (Table 1).

With regard to the differences between the first and third time periods, the number of factual references from the presidency or the directorate of the Asylum on the Feast of Saint Anthony or the Feast of the Holy Innocents drops drastically (from 14 and 13 to only one). The number of communications about elections for directorate also drops, decreasing from 12 to none. Equally meaningful and, it seems to us, more substantial differences are noted in the references praising and criticizing the Asylum. This result is because in praise coming from a source other than the presidency/directorate of the Asylum, it was possible to find four references to general praise/praise of the Asylum's mission and one reference to the order and cleanliness found in the Asylum, seven references praising the president and/or the directorate, six references on the cleanliness and order of the Asylum, and three references in praise of the general character of or on the mission of the Asylum Thus, there were a total of five more general praising references from the first period covering 21 years and a total of 16 praising news stories in the third period covering 12 years, with various references clearly being directed at the president of the directorate in office. Regarding the criticisms from the president/directorate of the Asylum source, in the first period, we found one reference focused on criticizing external criticisms of the Asylum and two criticisms from other sources that consisted of criticisms of the Asylum's previous administration (Table 1).

In short, the first period is characterized as being essentially factual in the types of news stories published, with many having the directorate/president of the Asylum as the source and including the call for elections, information on election results, invitations to the Feast of Saint Anthony and the Feast of the Holy Innocents, and communication and/or acknowledgements of donations. In the third period, there is the novelty of the existence of several news stories with content (very) clearly praising the activity of the directorate, especially its president.

The three different columns correspond to three different Asylum administrations (different presidents). During the entire first period (from 1858 to 1879), the president was Father João Pedro d'Ávila (Serpa, 2015c). With the departure of this president, the Asylum began to suffer, finding itself in a precarious situation (second period, from 1880 to 1882). At the end of 1883, an administrative commission was appointed, with António Pimentel da Silveira serving as president. da Silveira was named president of the directorate of the Asylum in 1885, transitioning out of the administrative commission and acting as president of the directorate of the Asylum during the entire third period (from 1883 to 1895) (Minutes of the Asylum for the Disadvantaged Children of Horta. From 10-01-1883 to 04-07-1897).

A relationship seems to exist between the type of news stories and the president of the directorate of the Asylum. How can one grasp and understand these results? We delve into these data through a qualitative analysis, which is presented below.

\subsection{Sharing of Institutional Information}

In the two periods compared, the importance of factual references is clearly maintained. These factual references are either obligatory or informative and voluntary on the part of the president/directorate of the AIDH, and they are primarily related to the Feast of Saint Anthony, the Feast of the Holy Innocents, donations, and benefactors. Such factual references also have the Asylum's management as their source, with the communication of donations and/or references to benefactors and elections communications standing out.

The persistence of information on donations and reference to benefactors, very often with explicit acknowledgements, is understood in large part by the need to cultivate a good relationship with benefactors, owing to the Asylum's great dependence on external private funding during these periods, even as a state dimension takes on a growing relative importance. In relation to the economic situation, the Asylum progressively began to generate more of its own ordinary revenue from forums, fees, and dues paid by the Brothers, interest from public debt products (generally resulting from private donations), and bank account interest. These funding sources made the AIDH progressively less dependent on external contingencies, generating extraordinary revenue (such as alms boxes in the school, the church, and the public market, in addition to donations from benefactors, whether of goods, services, or cash). In addition to the increase in self-generated income, the incidence of state subsidies for the maintenance of Asylum, both in terms of physical space and support of residents and internal operations, is increasingly observed. The state subsidies begin to constitute a greater share of the Asylum's funding, and their allocation to the AIDH becomes more regular (Serpa, 2015c).

Because of the Asylum's extremely precarious financial situation, which was initially very dependent on private funding, the visibility given to support appears to be truly important, as is observed in the acknowledgement of a benefactor living in the Brazilian Empire to whom the dispatch of a copy of $O$ Fayalense is referenced (Acknowledgement, 24 January 1873, in Copy of Letters of the Brotherhood of Saint Anthony and the Asylum of 
Disadvantaged Children. From April 1872 to 6/14/1878). The same situation is observed in news stories such as that transcribed below:

The Board of Directors of the asylum for the disadvantaged children of this city will order, on the 12th of the current month at 10 o'clock, the singing of a mass and a dirge in the asylum's church, because of the anniversary of the passing of His Excellency, Commander Joaquim de Borje Freire, celebrating the soul of such a great benefactor: the brothers of the brotherhood of Saint Anthony and of said asylum beseech the goodness of the public in attending those religious acts, so they can give a public testimony of gratitude to the remembrance of the man whose heart is recorded in the memory of the innocent poor who are orphans in this world, at the mercy to the rigors of time and all sorts of miseries; sharing with these unfortunates the abundant bread of charity. Horta, 11 January 1874. The executive president, João Pedro d'Ávila (O Fayalense, 1874 January 11, p. 4);

$[\ldots]$ the administration of this institute deserves to be not only praised but assisted because the income of the institute is very small (O Fayalense, 1890 January 12, p. 2);

[...] could appreciate the cleanliness and good order that reign in that hospice of charity, to which Mr. António Pimentel da Silveira, steward of the same, dedicates the greatest of attention, both in the internal administration and in the taking of steps for the livelihoods of the girls housed there. (O Fayalense, 1890 June 29, p. 3)

Without taking away the importance of the sympathy generated by the girls, who were abandoned and/or in difficult situations, one possible interpretation of the existence of private benefactors is the instability in the social order that the girls could create, a factor that makes it possible to understand the need to help, and thus control, them. Additionally,

[...] almsgiving was part of the habits of the very well-off, who, by religious traditions and by questions of social status, were accustomed to be charitable to the poor. Justifying their fortune, easing their conscience and simultaneously making charity an indispensable palliative that, in the nineteenth century, overcoming the extinction of the religious orders and the slowness of state intervention. (Matos \& Silva, 2008, p. 110)

In relation to celebratory moments, which are also times when the institution interacted with the community, the search for good relations with the surrounding community is clearly evident in these two periods, with the main festivities being the Feast of the Holy Innocents (the date of the asylum's establishment) and the Feast of Saint Anthony (Serpa, 2013). These festivities are publicized as typically involving the opening of the feast to the general public; trezenas (a 13-day period of prayer prior to a saint's feast) in the Church of Saint Anthony, connected to the Asylum; invitations to various figures to attend mass; the feast mass; the distribution of awards to the residents; lunch for the invitees; lunch for the residents, served by figures and attended by the general public; and Asylum openings to the public. These celebrations are frequently publicized in the newspaper $O$ Fayalense:

Last Sunday in the church of Saint Anthony, the feast dedicated to this saint was celebrated, which could not take place on the very day. There was a large attendance.

Some gentlemen and many common people attended the dinner for the residents. Before dinner, the children sang a hymn in honor of God for having saved them from misery and from hunger. It is an uplifting act and one that warms the heart (O Fayalense, 1862 June 29, p. 4);

The attendance was great, both in the morning and in the afternoon.

The poor residents had their dinner, offered by the board of directors, which was served by the ladies and gentlemen who were present. The praiseworthy artists' philharmonic, which played during the mass, also played at the residents' dinner.

The number of residents today is 17: it began with 6 . Public charity has been the inexhaustible source on which this pious institution has procured the means for its sustenance; and it will not lack public charity at any time. Institutions of that nature are always providentially protected. (O Fayalense, 1867 June 30, p. 4)

It was also a custom on a feast day to open the Asylum to those who wanted to visit it, with the possibility of examining the account books, a practice that, in the news stories collected, was not observed with such emphasis in the third period:

It is equally made public that on this day the account books of its management will be opened in the asylum's lounge to be examined, not only by the brotherhood, but by all people who are interested in 
them (O Fayalense, 1872 June 9, p. 4);

$1^{\text {st }}$ At 10 o'clock in the morning in the school room, the administrative commission, the residents, the teacher and visitors will meet to distribute awards, it being allowed by the president at this time the opportunity to speak to those who wish it.

$2^{\text {nd }}$ After this act will begin the religious feast, consisting of the Eucharistic adoration, sung mass, and sermon.

$3^{\text {rd }}$ Once the mass ends, there will follow a dinner with the residents, which all the invitees, the administrative commission, and other people who wish to will attend. (O Fayalense, 1883 December 23, p. 3)

Some differences between the first and the third period are evident. In the first period, the president frequently invites the readers of this newspaper to the feasts, publicizing the invitations to them and also acknowledging the patrons (benefactors, priests, musicians) for their various contributions to the feasts. However, the number of factual references originating from the president or the directorate of the Asylum with regard to the Feast of Saint Anthony or the Feast of the Holy Innocents drops dramatically in the third period (decreasing 14 and 13 to one), as do communications about elections for the directorate, which decreases from 12 to none. This scenario is not due to a statutory change, given that the statutes remained the same.

The need to maintain good relations with the outside leads to other occasions for contact with the outside world, during which controlled access to the residents is granted. This practice is observed in the news stories published, as is seen in the following examples:

[demonstrations of mourning due to the death of King Pedro V] On the 18th, His Excellency, the Civil Governor of the District, ordered a mass celebrated in the church of Saint Anthony, which he along with his entire staff, the commander of the military subdivision, and the employees of the treasury division attended. His Excellency gave that day a dinner to the residents. [...] On that same day, the administration of the Asylum for the Disadvantaged Children ordered the celebration of a sung mass, and a dirge, which the civil, judicial, and military authorities attended. The residents appeared dressed in black [...]. We are told that the mourning garments were donated by the righteous board member, Mr. João Cristiano da Silva Parole. Of the gentlemen invited, two offered to provide dinner to the residents, one for three days and the other on the day of the feast. (O Fayalense, 1861 December 22, p. 2)

\subsection{The Strategic Relationship of the President/Directorate of the Asylum with the Newspaper O Fayalense}

The Asylum's public image is positive at various times and during different administrations at the general level of appreciation:

Public charity has been the inexhaustible source on which this pious institution has procured the means for its sustenance; and it will not lack public charity at any time. Institutions of that nature are always providentially protected (O Fayalense, 1867 June 30, p. 4);

They enjoy the satisfaction of knowing that their money has been holily and religiously employed in the work of mercy for whom it is destined. (O Fayalense, 1866 June 24, p. 1)

According to the opinion pieces published in the newspaper $O$ Fayalense, in the first period, there are four references in praise of the general character and/or toward the mission of the Asylum and one to the cleanliness and order of the Asylum. In the third period, three references in praise of a general character and/or toward the mission of the asylum are identified, in addition to six references to the cleanliness and order of the asylum: "the asylum was open during the day to people who wanted to visit it, and was quite clean and orderly" (O Fayalense, 1876 June 25 , p. 4); "The asylum's building was visited by many people, all recognizing the great cleanliness and good order that exists there" (O Fayalense, 1889 June 16, p. 3).

In relation to the public image of the Asylum's operation, there are substantial differences in praise, especially in relation to the merit of the presidency. These differences occur because in praise that comes from a source outside of the presidency/directorate of the Asylum, in the first period, there are four references in praise of the general character and/or about the mission of the Asylum and one about its order and cleanliness; in the third period, there are seven references in praise of the president and/or the directorate, six references in praise of the cleanliness and order of the Asylum, and three references in praise of the general character and/or about the mission of the Asylum. Thus, there are a total of five more general references in praise in the first period, covering 21 years, and 16 references in praise in the third period, covering 12 years, with various praises clearly being directed at the president of the directorate in office. 
To understand the occurrence of seven references in praise of the action of the president and/or directorate in the second period, when none were found in the first period, it is necessary to contextualize the management of the Asylum. With the departure of Father João Pedro d'Ávila as president, the Asylum suffers, finding itself in a precarious situation both financially and at the level of internal operations. On 1 October 1883, an administrative commission presided over by António Pimentel da Silveira, who would come to be named president of the directorate in 1885, is appointed (Session of 30 June 1885, in Minutes of the Asylum of the Disadvantaged Children of Horta. From 10-1-1883 to 4-7-1897).

With the entrance of António Manuel da Silveira, a full-scale public relations strategy on the part of the management of the Asylum is initially observed, according to the data collected (Minute of 23 October 1883, about the evaluation of the Asylum, which is one of the first minutes of this administration) (O Fayalense, 1883 November 25, p. 1), and it is repeated the following year (O Fayalense, 1884 January 13, pp. 1, 2).

The celebration of the 25th year of the Asylum of the Disadvantaged Children was celebrated concurrently with the Feast of the Holy Innocents in the Church of Saint Anthony. During the celebration, after the invitees' lunch, the lunch for the residents followed, being attended by the former (as had been the tradition). This celebration of the Asylum's 25 years is richly documented in O Fayalense; appreciation of the role of Father João Pedro d'Ávila, the first president and one of the Asylum's protagonists, is also observed:

The Rev. Ávila was received by the president of the commission, who accompanied him to the temple door, where the Asylum's regent and her students awaited him. When the innocent girls, with their white clothing, symbol of the candor of their innocent hearts, approached the old priest to kiss his hand, he could not overcome the emotion that he felt and the tears dampened their faces. So moved, he went to the church's chapel, where he prayed [...] the honorary royal chaplain, Mr. José Veríssimo Ribeiro, in high phrases, told the history of the twenty-five years of the existence of that institution, on whose foundations supported counselor António José Vieira Santa Rita, and the Revs. Henrique da Pureza Greaves and João Pedro d'Ávila [...]. The acts of dedication and the efforts of the first steward, Rev. João Pedro, were praised. (O Fayalense, 1884 January 6, pp. 2-3)

With the new president, $O$ Fayalense begins to publish explicitly praiseful news stories about the Asylum's administration. These pieces are not only institutional glorifications, such as "it is well deserving of continued donations from public charity" ( $O$ Fayalense, 1894 December 30, p. 3), but also comparisons with prior administrations and situations. Various examples of explicit praise of the activity of the president and the educational staff, including their achievements, follow and are presented because of their clarity:

The worthy administrative commission of the asylum for the disadvantaged children of this city has no need of our praises, because the public adequately evaluates its good services and the dedication with which it works to give to the asylum a life stripped of pecuniary embarrassments that would obstruct its modest progress $[\ldots]$ it becomes worthy of the protection of all ( $O$ Fayalense, 1884 January 6, pp. 2,3);

The asylum's building was open to the public, being visited by a large number of people, who could appreciate the cleanliness and good order that reign in that hospice of charity, to which Mr. António Pimentel da Silveira, steward of the same, dedicates the greatest of attention, both in the internal administration and in the taking of steps for the livelihoods of the girls housed there. (O Fayalense, 1890 June 29, p. 3)

The teaching at the Asylum and the education provided to the residents is praised ( $O$ Fayalense, 1890 January 5 , p. 3). The director herself is equally praised in $O$ Fayalense, highlighting the educational success, whether at the level of the training of the students for domestic work or in education:

$[\ldots]$ and only one woman exercises the role of director and professor of all the disciples taught there, $[\ldots]$ whom, on behalf of our fellow citizens, we thank for the affection and devotion that for three years she has paid to the underprivileged students, housed in the place named by the Infante D. Luiz as the city of Horta (O Fayalense, 1890 January 12, p. 2);

[About the forthcoming marriage of a student] she is the first student of that charity establishment who has left to enter into the conditions of an honorable life, and which in society offers her the reputation and the esteem that an honest woman deserves. (O Fayalense, 1885 January 11, p. 3)

Specifically, with regard to the criticism originating from the president/directorate of the Asylum, a reference is found in the first period that focuses on criticizing external criticisms of the Asylum, which, "by confusion of some scathing language", speaks of the Asylum having received a "large donation" (O Fayalense, 1870 December 18, p. 4). By contrast, in the second period, criticisms from other sources that consist of criticisms of 
the previous administration of the Asylum are observed:

The entire asylum building exhibits the greatest cleanliness and order. The moral education of the children is carefully observed, as the nutritional regime is no less scrupulously attended to, conferring the residents a satisfactory appearance of health and appropriate nutrition.

The previous administrations made the regime of that establishment to benefit the poor residents considerably better, without burdening the asylum, on the contrary, even increasing its incoming funds. The present board of directors follows the same path, and cultivates the best wishes of successful performance of its task.

Administrations such as this merit total confidence, and inspire in generous hearts the will to come together in benefit of houses of charity ( $O$ Fayalense, 1886 January 3, p. 3);

The students are no longer emaciated children, the stunted children of the asylum. They are of good color and nourishment, and merely for this humanitarian improvement, the administration of this institution deserves to be not only praised but also assisted because the income of the institute is quite small. ( $O$ Fayalense, 1890 January 12, p. 2)

Based on the information collected, the difference in the public image facilitated its action: in the third period, the management of the Asylum counted on manifest support, as opposed to the situation perceived by the president in the first period, Father João Pedro d'Ávila, which consisted of a heated dispute, in part published by O Fayalense, concerning the possibility that, in 1872, the management of the AIDH would be awarded to the Love of the Fatherland Society [Sociedade Amor da Pátria] (Historical report about the asylum for the disadvantaged children in the city of Horta, 1884; Serpa, 2015d). With regard to the Love of the Fatherland Society, Lima (1981, p. 507) writes: "the current Love of the Fatherland club was not, at the start, a specifically recreational society but rather, singularly and simply, a Masonic lodge similar to the others that then bubbled up in the shade, like mushrooms, in every corner of Horta". This dispute also had its moments of exchange in local newspapers. Regarding these moments, we highlight one that occurred between an editor of $O$ Fayalense and Father d'Ávila, each one justifying his positions on the state of the Asylum and the role exercised by the brotherhood. The editor notes the opportunities created by the substantial improvement of the Asylum's budget, stressing that the board of directors itself, in its 1870-1871 budget, recognizes the dependence on extraordinary income (Historical report about the asylum for the disadvantaged children in the city of Horta, 1884, p. 46), which would be enabled by the Love of the Fatherland Society assuming its management. However, for Father d'Ávila, "The facts prove that the asylum has always paid its expenses and that it has always left some balance in its favor, and against these facts there are no arguments" (Historical report about the asylum for the disadvantaged children in the city of Horta, 1884, p. 52), in a logic that "the establishments of this order always have the blessing of Providence, and this, our asylum, can be presented as proof of this assertion. The resources have always appeared and without some humiliating conditions for the administration of the asylum itself" (Historical report about the asylum for the disadvantaged children in the city of Horta, p. 42). The result was Father João Pedro d'Ávila's being able to continue in his capacity as president of the Asylum (for an in-depth discussion of this episode, see Serpa, 2015d).

In this dimension of the influence of public image on organizational administration, the president acting in the third period, António Pimentel da Silveira, counted on increased cooperation.

\section{Discussion}

In this case study of the influence of institutional communication, which focused on the importance of public image in organizational administration in education, the AIDH was analyzed through a collection of news stories in a single newspaper-O Fayalense-from the founding of the Asylum until the end of this weekly publication (1858-1895).

From the results obtained, factual information (on the celebrations occurring in the Asylum, communications of donations received and acknowledgements of benefactors, or institutional information on elections for the Asylum's directorate), praise (with regard to the Asylum's mission, its operation, or its administration), and criticism (such as responses to external criticisms, criticisms of previous management, and references to the Asylum's precarious circumstances) are observed in the published references concerning the Asylum. These references vary substantially during the period in question, and situations of a more manifest influence of the newspaper's position, translated into news stories published on the Asylum's organizational management, are observed.

In the time period analyzed, it is observed that the management of the AIDH experienced a relationship with the 
outside and, specifically, at the level of public image. The need to project a positive image to the outside occurs because of the legitimacy sought for the activities performed there but, equally, because of the need for sources of private funding.

The implication of this study is that despite a certain organizational autonomy in relation to the environment external to the organization, the organization was influenced, directly or indirectly, by the contact established with the outside world, for example, in the search for resources and/or in the attempt to (re)legitimize the purposes and activities of the organization. Therefore, the importance of projecting a positive public image, especially a positive image that is supportive of the management, should not be overlooked for the organizational administration, in any setting, to have greater chances of success.

One of the limitations of this study is the inability to generalize the results obtained in this case study, which is a situational analysis. Another limitation derives from the organization in question, the time period, and the very specific spatial area covered in the collection of news stories (some months in the years 1858 to 1895 , in the setting of a somewhat remote island), which will have to be taken into account in future investigations of the development and the deepening of the meaning of public image in organizational administration in education.

\section{Acknowledgments}

We would like to thank Dr. Gustavo Pereira, Dr. Joaquim Ramos, and Dr. Ana Cláudia Vicente for their assistance in the collection of news stories relating to the Asylum of Disadvantaged Children of Horta in $O$ Fayalense.

\section{References}

Alvesson, M. (2013). Understanding organizational culture (2nd ed.). London, UK: SAGE Publications.

Bardin, L. (1995). Análise de Conteúdo [Content Analysis]. Lisboa: Edições.

Crozier, M., \& Friedberg, E. (1992). L'acteur et le système. Les contraintes de l'action collective. Paris: Éditions du Seuil.

Direção do Asilo de Infância Desvalida da Horta [Directorate of the Asylum for the Disadvantaged Children of Horta]. (1878). Cópia de Oficios da Confraria de Santo António e Asylo de Infância Desvalida. Desde Abril de 1872 a 14/6/1878 [Copies of Letters from the Brotherhood of Saint Anthony and Asylum for Disadvantaged Children. From April 1872 to 6/14/1878].

Direção do Asilo de Infância Desvalida da Horta [Directorate of the Asylum for the Disadvantaged Children of Horta]. (1897). Actas do Asylo de Infância Desvalida da Horta. Desde 1-10-1883 a 7-4-1897 [Minutes of the Asylum for the Disadvantaged Children of Horta. From 10-1-1883 to 4-7-1897].

Fernandes, A. A. S. (2004). Uma Obra Ímpar Abençoada por Santo António. Casa de Infância de Santo António-Horta [A Unique Institution Blessed by St. Anthony. Saint Anthony Children's Home-Horta]. Lisboa: self-published.

Friedberg, E. (1993). Le pouvoir et la règle. Dynamiques de l'action organisée. Paris, France: Éditions du Seuil.

Goffman, E. (2007). Manicômios, prisões e conventos [Asylums, prisons and convents]. São Paulo, Brazil: Editora Perspectiva.

Hilman, H., \& Siam, M. (2014). The influence of organizational structure and organization culture on the organizational performance of higher educational institutions: The moderating role of strategy communication. Asian Social Science, 10(13), 142-154. http://dx.doi.org/10.5539/ass.v10n13p142

Hofstede, G. (2003). Culturas e organizações. Compreender a nossa programação mental [Cultures and organizations. Understanding our mental programming]. Lisboa: Edições Sílabo.

Lemos, R. R. G. de. (1958). Asilo de Infância Desvalida da Horta. 1858-1958. Trabalho manuscrito de comemoração de um século de existência [Asylum for the Disadvantaged Children of Horta. 1858-1958. Manuscript celebration one century of existence].

Lima, L. C. (2011a). Concepções de escola: para uma hermenêutica organizacional [School concepts: for an organizational hermeneutics]. In Licínio C. Lima (Ed.), Perspectivas de análise organizacional das escolas [Perspectives on the organizational analysis of schools] (pp. 15-57). Vila Nova de Gaia, Portugal: Fundação Manuel Leão.

Lima, L. C. (Ed.). (2011b). Perspectivas de análise organizacional das escolas [Perspectives on organizational analysis of schools]. Vila Nova de Gaia, Portugal: Fundação Manuel Leão. 
Lima, M. (1981). Anais do Município da Horta (História da Ilha do Faial) [Annals of the Municipality of Horta (History of Faial Island)]. East Providence: A \& H Printing, Inc.

Lobão, C. M. G. (1998). Casa de Infância de Santo António - Subsídios para a sua História [Saint Anthony Children's Home-Subsidies for its History]. Horta: Casa de Infância de Santo António.

Matos, P. L., \& Silva, S. S. (2008). Oscilações populacionais, grupos e comportamentos sociais [Population movements, groups and social behavior]. In A. T. de Matos, A. de F. de Meneses, \& J. G. R. Leite (Eds.), História dos Açores. Do descobrimento ao século XX [History of the Azores. From discovery to the twentieth century] (Vol. 2, pp. 83-120). Angra do Heroísmo: Instituto Açoriano de Cultura.

Perrenoud, P. (1994). A organização, a eficácia e a mudança, realidades construídas pelos atores [Organization, effectiveness and change, realities constructed by actors]. In M. G. Thurler, \& P. Perrenoud (Eds.), A Escola e a Mudança. Contributos sociológicos [The School and Change. Sociological Contributions] (pp. 133-159). Lisboa: Escolar Editora,

Schein, E. H. (2010). Organizational culture and leadership (4th ed.). San Francisco, CA: Jossey-Bass.

Serpa, S. (2013). Celebrações e linguagem na imagem do Asilo de Infância Desvalida da Horta, Portugal, 1858-1910 [Celebrations and Language on the Image of Asilo de Infância Desvalida da Horta, Portugal, 1858-1910]. Revista de Ciências Humanas, 47(2), 331-343. http://dx.doi.org/10.5007/2178-4582.2013v47n2p331

Serpa, S. (2015a). O contributo do conceito de instituição total para uma leitura empírica de um contexto educativo [The contribution of the concept of total institution for an empirical reading of an educational context]. In APS (Ed.), 40 anos de democracia(s): progressos, contradições e prospetivas [40 years of democracy(ies): Progress, contradictions and prospects]. Atas do: VIII Congresso Português de Sociologia (pp. XX-XX). Lisboa, Portugal: Associação Portuguesa de Sociologia. http://www.aps.pt/viii_congresso/VIII_ACTAS/VIII_COM0101.pdf

Serpa, S. (2015b). Regulação e autonomia na procura de legitimidade na fundação do Asilo de Infância Desvalida da Horta [Regulation and autonomy in the search for legitimacy in the founding of the asylum for the disadvantaged children of Horta]. In A. P. Almeida, L. L. Dinis, \& G. R. da Silva (Eds.), Políticas e Práticas de Administração e Avaliação na Educação Ibero-Americana - Actas do IV Congresso Ibero-Americano de Políticas e Administração da Educação - 2014 [Management Policies and Practices and Evaluation in Ibero-American Education-Proceedings of the 4th Ibero-American Congress of Educational Policy and Administration-2014]. Lisboa, Portugal: Fórum Português de Administração Educacional.

Serpa, S. (2015c). Autonomy in Leadership: A case study of the founder's role in establishing an organization. Asian Social Science, 11(13), 212-220. http://dx.doi.org/10.5539/ass.v11n13p212

Serpa, S. (2015d). The non-sharing of organizational culture: A case study examining the management perspective. Asian Social Science, 11(10), 221-230. http://dx.doi.org/10.5539/ass.v11n10p221

Newspaper O Fayalense:

O Fayalense, 1861 December 22, p. 2.

O Fayalense, 1862 June 29, p. 4.

O Fayalense, 1866 June 24, p. 1.

O Fayalense, 1867 June 30, p. 4.

O Fayalense, 1870 December 18, p. 4.

O Fayalense, 1872 June 9, p. 4.

O Fayalense, 1874 January 11, p. 4.

O Fayalense, 1876 June 25, p. 4.

O Fayalense, 1883 November 25, p. 1.

O Fayalense, 1883 December 23, p. 3.

O Fayalense, 1884 January 6, pp. 2-3.

O Fayalense, 1884 January 13, pp. 1, 2.

O Fayalense, 1885 January 11, p. 3. 
O Fayalense, 1886 January 3, p. 3.

O Fayalense, 1889 June 16, p. 3.

O Fayalense, 1890 January 5, p. 3.

O Fayalense, 1890 January 12, p. 2.

O Fayalense, 1890 June 29, p. 3.

O Fayalense, 1894 December 30, p. 3.

\section{Copyrights}

Copyright for this article is retained by the author(s), with first publication rights granted to the journal.

This is an open-access article distributed under the terms and conditions of the Creative Commons Attribution license (http://creativecommons.org/licenses/by/3.0/). 